日作紀（Jpn. J. Crop Sci.）86（2）：119-128（2017）

\title{
ダイズの耕うん同時㽞立て狭畦栽培における適正栽植密度 一密植適応性が異なる新潟県ダイズ奨励品種の比較—
}

\author{
藤田与一 ${ }^{1,3)} \cdot$ 川上修 ${ }^{1)} \cdot$ 黑田智久 ${ }^{1)} \cdot$ 服部誠 ${ }^{2)} \cdot$ 樋口泰浩 ${ }^{1)} \cdot$ 南雲芳文 $^{1)} \cdot$ 高橋能彦 $^{3)}$ \\ (1) 新潟県農業総合研究所作物研究センター, ${ }^{2}$ 新潟県農林水産部, ${ }^{3)}$ 新潟大学大学院自然科学研究科)
}

\begin{abstract}
要旨：密植適応性が異なる新潟県ダイズ奨励品種「エンレイ」および「あやこがね」を用いて, 重粘土質水田転換畑 におけるダイズ耕うん同時畧立て狭畦栽培の適正な栽植密度を検討した。ダイズ群落内の相対光合成有効放射（相対 PAR）量は, 両品種ともに狭畦栽培では密植になるほど低くなるが, 開花期頃にはいずれの栽植密度でも $10 \%$ 以下と なり十分な雑草抑制効果が得られた。成熟期の生育は両品種とも密植になるほど徒長気味の生育となり，倒伏程度は 「エンレイ」では栽植密度 17.8 株 $\mathrm{m}^{-2}$ 以上で，慣行栽培（条間 $75 \mathrm{~cm}$ ，栽植密度 8.9 株 $\mathrm{m}^{-2}$ ) より大きくなった。「 やこがね」は狭畦栽培と慣行栽培とで倒伏程度に差がなかった，収量は両品種とも密植になるほど増加する傾向とな り,「エンレイ」では栽植密度 17.8 株 $\mathrm{m}^{-2}$ 以上で,「あやこがね」では栽植密度 13.3 株 $\mathrm{m}^{-2}$ 以上で, 慣行栽培より有 意に増加した. 本研究結果において, 狭畦栽培の場合「エンレイ」では倒伏軽減の観点から栽植密度 8.9 13.3 株 $\mathrm{m}^{-2}$,「あやこがね」では増収効果の観点から $13.3 \sim 26.7$ 株 $\mathrm{m}^{-2}$ が適正栽植密度と判定された.
\end{abstract}

キーワード : 畒立て狭畦栽培, 栽植密度, 収量, 相対 PAR, ダイズ, 倒伏, 密植適応性.

近年ダイズ生産において, 条間を従来よりも半分程度狭 めて栽培を行う「狭畦栽培」の研究が積極的に行われてい る. 狭畦栽培では従来よりも栽植密度を高めることができ, 密植の効果で増収が期待できる（中世古・後藤 1975, 齊藤 ら 1998, 池田 2000)。また狭畦によりダイズ自身の茎葉に よって早期に，地表面をマルチのように覆う（野口ら 1977, 星川 1996）効果があり, 雑草抑制効果が早期に得ら れることも期待できる。新潟県においては後者の効果に注 目し，狭畦栽培の普及を図っており，排水性の悪い県内の 水田転換畑では「耕うん同時畧立て狭畦栽培」が適するこ と，また耐倒伏性の高いダイズ品種「タチナガ八」を用い た場合, 栽植密度が执よそ 14 株 $\mathrm{m}^{-2}$ の条件に扔いて, 中耕 · 培土を省略しても雑草抑制効果が得られたことを確認した (藤田ら 2014).

本県の 2014 年産のダイズ作付面積は 5,170 ha で, 全国 で 7 位である. 近年, 1 経営体あたりの大豆作付面積は拡 大傾向であり，一部の圃場では中耕・培土作業等，管理作 業が間に合わずに適期に行えなくなっている。また中耕・ 培土実施期間は梅雨にあたり, 作業が可能な日は少なく, さらに重粘土地带が広がる本県では降雨後も圑場が乾きに くく，好条件で中耕・培土作業が行われることはほとんど ない．このことから適期に中耕・培土作業を実施できずに 雑草を繁茂させてしまい, 収量および品質の低下につなが る事例が見られる。このため, 中耕・培土の省略につなが り, かつ雑草発生を抑え, ダイズの安定生産を図るため, 耕うん同時畧立て狭畦栽培の導入や普及が期待される. 作 付けされている県ダイズ奨励品種は「エンレイ」と「あや こがね」であり，本県でダイズの耕うん同時畧立て狭畦栽 培を広く普及させるためには, 両品種に対する栽培技術の
開発が欠かせない.

ダイズ育成地による倒伏抵抗性評価は「エンレイ」，「あ やこがね」ともに「強」判定である(御子柴ら 1974, 矢ケ 崎ら 2000）が, 実際に新潟県内で栽培した場合,「エンレイ」 は「あやこがね」より，密植にすると倒伏しやすい傾向が あり,「エンレイ」の方が密植適応性は低いと考えられる。 新潟県に扔けるダイズの $\mathrm{m}^{2}$ 当たりの目標苗立数も, 6 月上 旬播種の場合「エンレイ」は 9 10 本に対して「あやこが ね」は 14 16 本と設定し,「エンレイ」の方を疎植として いる. 光の競合によって徒長, 倒伏を誘発しやすい狭畦栽 培において, 密植適応性が低い「エンレイ」では倒伏被害 を抑えるため, 耕うん同時畧立て狭畦栽培の適正な栽植密 度を検討する必要がある.ダイズ耕うん同時㽞立て狭畦栽 培における適正な栽植密度の報告例として, 片山ら（2012） が北陸地域の重粘土圃場における「エンレイ」の耕うん同 時畧立て狭畦栽培で, 水稲一オオムギーダイズの 2 年 3 作 体系に㧈ける 6 月中，下旬播種の晚播栽培において減収を 軽減するための栽植密度を示している。しかし本県では単 作ダイズが主体で 6 月上旬頃に播種作業が行われており, この頃の播種における, 密植適応性の異なるダイズ品種の 耕うん同時畧立て狭畦栽培の適正な栽植密度を解明するこ とが重要と考える。

そこで本研究では, 密植適応性が異なると考えられる新 潟県ダイズ奨励品種 2 品種を用いて, 栽植密度の違いがダ イズ 2 品種に与える生育特性の違いを解析し, 新潟県の重 粘土戋場に扔ける耕うん同時畧立て狭畦栽培の適正な栽植 密度を検討した。

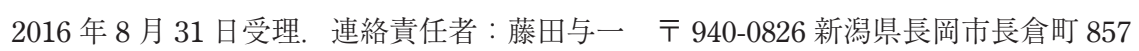

TEL 0258-35-0836, FAX 0258-35-0021, yfujita@ari.pref.niigata.jp 
第 1 表 新潟県における「エンレイ」および「あやこがね」の生育特性.

\begin{tabular}{|c|c|c|c|c|c|c|c|c|c|c|c|}
\hline 播種区分 & 品種 & $\begin{array}{l}\text { 開花期 } \\
(\text { 月日 })\end{array}$ & $\begin{array}{l}\text { 成熟期 } \\
\text { (月日) }\end{array}$ & $\begin{array}{c}\text { 倒伏程度 } \\
(0-5)\end{array}$ & $\begin{array}{c}\text { 主茎長 } \\
(\mathrm{cm})\end{array}$ & $\begin{array}{l}\text { 主茎節数 } \\
\left(\text { 節 株 }{ }^{-2}\right)\end{array}$ & $\begin{array}{c}\text { 分枝数 } \\
\left(\text { 本 株 }{ }^{-2}\right)\end{array}$ & $\begin{array}{l}\text { 茎太 } \\
(\mathrm{mm})\end{array}$ & $\begin{array}{c}\text { 萊数 } \\
\left(\text { 萊 } \mathrm{m}^{-2}\right)\end{array}$ & $\begin{array}{c}\text { 百粒重 } \\
(\mathrm{g})\end{array}$ & $\begin{array}{l}\text { 子実重 } \\
\left(\mathrm{g} \mathrm{m}^{-2}\right)\end{array}$ \\
\hline \multirow{2}{*}{ 標準播 } & エンレイ & $7 / 22$ & $10 / 11$ & 0.7 & 54 & 13.8 & 4.9 & 9.2 & 635 & 32.0 & 33.9 \\
\hline & あやこがね & $7 / 23$ & $10 / 14$ & 0.4 & 52 & 14.0 & 4.9 & 10.1 & 656 & 30.4 & 35.1 \\
\hline \multirow{2}{*}{ 晚播 } & エンレイ & $8 / 2$ & $10 / 16$ & 0.5 & 53 & 12.3 & 2.8 & 6.3 & 535 & 30.0 & 24.6 \\
\hline & あやこがね & $8 / 3$ & $10 / 19$ & 0.0 & 53 & 12.8 & 3.2 & 6.9 & 559 & 30.7 & 26.7 \\
\hline
\end{tabular}

新潟県農業総合研究所内圃場に打ける，2005～2014 年の 10 ケ年平均值である。標準播は 5 月 30 日に $\mathrm{m}^{2}$ 当り 8.9 粒を播種し，晚播は 6 月 20 日に $\mathrm{m}^{2}$ 当り 13.3 粒を播種した。倒伏程度は $0:$ 無, $1:$ 微, $2:$ 少, $3:$ 中, $4:$ 多, $5:$ 甚, を表す.

\section{材料と方法}

\section{1. 供試ダイズ品種の特性}

ダイズ品種は 2014 年の時点で新潟県奨励品種に指定さ れている「エンレイ」および「あやこがね」の 2 品種を供 試した。 県内における 2 品種の生育特性を第 1 表に示す. 標準播で「エンレイ」は10月 11 日に成熟し,「あやこがね」 は 10 月 14 日で「エンレイ」より成熟が 3 日程度遅い。倒 伏程度は「エンレイ」が「あやこがね」に比べて標準播で 0.3 , 晚播で 0.5 高く,「エンレイ」の方が倒伏しやすい 傾向がある。主茎長は標準播で「エンレイ」の方が長く, 茎太は標準播, 晚播ともに「エンレイ」の方が細い傾向が 見られ，「エンレイ」の方が倒伏しやすい株姿を呈する.

\section{2. ダイズの栽培概要および気象}

本研究は 2012～2014 年に，新潟県長岡市にある新潟県農 業総合研究所作物研究センター（以下, 所内）の水田転換

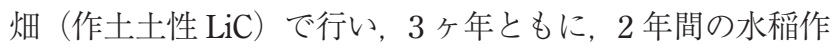
後の転換 1 年目となる固場で実施した。基肥散布は耕うん 前に行い, 2012 年は $\mathrm{N}, \mathrm{P}_{2} \mathrm{O}_{5}, \mathrm{~K}_{2} \mathrm{O}$ をそれぞれ $1.6 \mathrm{~g} \mathrm{~m}^{-2}, 6.0$ $\mathrm{g} \mathrm{m}^{-2}, 8.0 \mathrm{~g} \mathrm{~m}^{-2}$ 施用し, 2013，2014 年は $\mathrm{N}, \mathrm{P}_{2} \mathrm{O}_{5}, \mathrm{~K}_{2} \mathrm{O}$ を それぞれ $1.6 \mathrm{~g} \mathrm{~m}^{-2}, 4.0 \mathrm{~g} \mathrm{~m}^{-2}, 6.0 \mathrm{~g} \mathrm{~m}^{-2}$ 施用した。

播種様式は, 耕うん同時㽞立て狭畦栽培（以下, 狭畦区) では第 1 図のとおり，耕うんと同時に畧幅 $150 \mathrm{~cm}$ の平高 欲を形成し，平高畧の畧立て高さは約 $10 \mathrm{~cm}$ とした。栽植 密度は，平高㽞上にダイズを条間 $32 \mathrm{~cm}$ の 4 条，畧間を 54 $\mathrm{cm}$ （平均条間 $37.5 \mathrm{~cm}$ ）を基本とし，株間を変えて栽植密 度を 4 水準設定した。すなわち，株間 $30 \mathrm{~cm}, 20 \mathrm{~cm}, 15$ $\mathrm{cm}, 10 \mathrm{~cm}$ とし, $\mathrm{m}^{2}$ 当り栽植密度をそれぞれ 8.9 株, 13.3 株, 17.8 株, 26.7 株とした. 慣行栽培（以下, 慣 行区）では, 条間 $75 \mathrm{~cm}$, 株間 $15 \mathrm{~cm}$ （ $\mathrm{m}^{2}$ 当り栽植密度 8.9 株）に設定し,耕うん同時畧立て播種を行った。播種は 3 ケ 年とも，6月 6 日に行った。播種機はアグリテクノ矢崎社 製の目皿式播種ユニット「TDRG-U」を用いた。本機にお けるダイズの最小株間は $11 \mathrm{~cm}$ 設定までであるが，株間 10 $\mathrm{cm}$ の試験区を間引きで設定できるように，2 粒播種用目血 を用いて播種を行った。栽植密度の設定は狭畦区，慣行区 ともに株間 $11 \mathrm{~cm}$ の 2 粒播き設定で機械播種を行った後, おおよそ出芽が揃う第 1 複葉展開期頃に竹尺と剪定バサミ

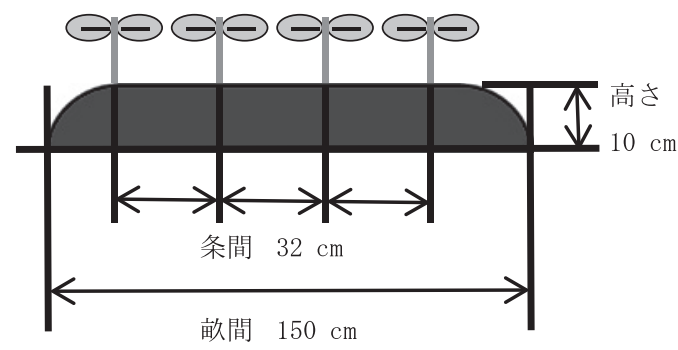

第 1 図 耕うん同時畧立て狭畦栽培の模式図.

を用いて, ダイズ株 1 本立ちで株間 $30 \mathrm{~cm}, 20 \mathrm{~cm}, 15 \mathrm{~cm}$, $10 \mathrm{~cm}$ となるように間引きして調整した。試験区 1 反復分 の面積は狭畦区では各栽植密度とも畧幅 $1.5 \mathrm{~m} \times$ 㽞の長 さ $5 \mathrm{~m}$, 慣行区では 2 条分 $1.5 \mathrm{~m} \times$ 畧の長さ $5 \mathrm{~m}$ とし, 各試験区ともに 3 反復分設けた.

除草体系は, 播種後に両区とも土壇処理除草剤として「ジ メテナミド・リニュロン粒剤」を散布した。 その後, 狭畦 区では播種後 1 ケ月以降に生育期除草剤「ベンタゾン液剤」 「キザロホップエチル水和剤」を散布し, 中耕培土は行わ なかった。慣行区は中耕培土を播種 25 日後頃に 1 回目を, その 2 週間後頃に 2 回目を実施し, 生育期除草剂を散布し なかった。病害虫対策は両区とも，播種前に「チアメトキ サム・フルジオキソニル・メタラキシル M 水和剤」を種 子塗抹し, 8 月上旬はアブラムシ類および葉巻害虫防除と して「MEP 乳剂」を散布した。ささらに， R2 期の 4 週後に 当たる 8 月下旬頃に紫斑病防除として「アゾキシストロビ ン水和剤」, 2 回目のアブラムシ類防除として「エトフェン プロックス乳剤」を散布し，9月上旬には子実害虫防除と して「ペルメトリン乳剤」を散布した。

以上の栽培概要は, 供試ダイズ 2 品種において共通で設 定した.

気象条件については，月別の日平均気温と日射量および 降水量は所内圃場に設置されている気象観測装置の記録を 用いた。 また，長岡市内の 1 時間雨量および最大瞬間風速 は, 気象庁公開の長岡観測地点の記録を用いた（気象庁 2015a).

\section{3. ダイズ生育調査}

播種 30 日後, 50 日後, 80 日後頃に, ダイズの主茎長, 
主茎節数, 一次分枝数を調査した。調査株は狭畦区および 慣行区ともに，1 反復につき生育中庸な連続 5 株を選定し た。

成熟期には倒伏程度を確認し, その後 1 反復につき狭畦 区では $2 \mathrm{~m} \times 4$ 条を，慣行区では $4 \mathrm{~m} \times 2$ 条を根部ごと抜き 取り，成熟期生育および収量調査を行った。成熟期生育調 査株は，播種 30 日後，50日後，80日後頃の生育調査と同 様の 5 株を用い，抜き取り前にカラースプレーで地際部を マーキングし, 抜き取り後はざ干しで 2 週間程度乾燥条件 で保管したのちに調査を行った。「主茎長」および「最下着 莢節位高」は抜き取り前に塗布したマーキングを目印とし て地際からの高さを測定した。「茎太」は主茎の子葉節と初 生葉節との節間中央部の長径を，ノギスを用いて測定した。

\section{4. ダイズ群落の地表面における相対 PAR 量の測定}

ダイズ生育調査と同時期に, LI-COR 社製 LI-190SA 光量 子センサーを用いて群落内の相対 PAR 量を測定した。測 定時刻は 16 時から 17 時頃, 晴天または曇天時に実施した。 狭畦区ではダイズ群落上の光量を測定し，次に中野ら （2001）の方法を参考として，平高畧上のダイズ 3 条間の, 隣接する 2 条の 2 株が対角線で交差する箇所の地表面を測 定した (第 2 図)。慣行区ではダイズ群落上と, 地表面で はダイズ 1 条間の隣接する 2 条の 2 株が対角線で交差する 箇所を測定した，加えて，狭畦区の地表面の測定では大豆 株元から $16 \mathrm{~cm}$ 程度離れて測定することから，慣行区でも 大豆株元から $16 \mathrm{~cm}$ 離した日表側，および日裏側の 2 点の 地表面の光量を測定した。測定後，両区とも3 点の地表面 光量の平均值を群落上光量で割り返し, 百分率に示した值 を相対 PAR 量とした.

\section{5. 統計解析}

ダイズ調査および相対 PAR 量の測定については，株式 会社社会情報サービス社製の統計解析ソフト「エクセル統
計 2008」を使用し, 年次および栽培法を因子とし, 多重比 較検定を行った。

$$
\text { 結 果 }
$$

\section{1. 気象的特徵}

月別の日平均気温，日射量および降水量を第 2 表に示し た。 2012 年は日平均気温が 9 月に平年より $2^{\circ} \mathrm{C}$ 以上高く,

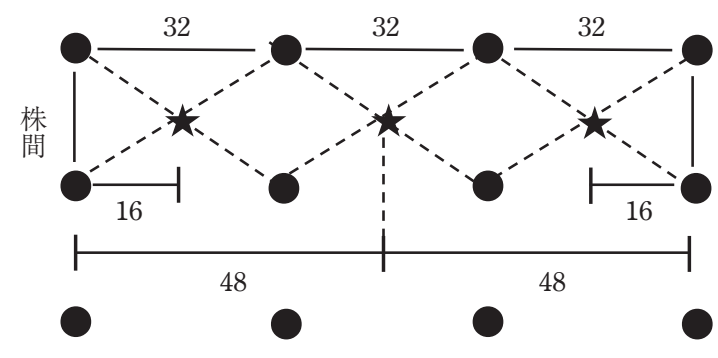

狭畦栽培

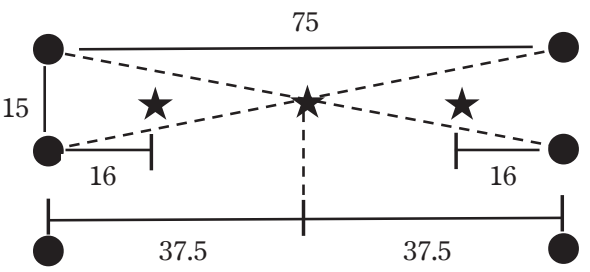

慣行栽培

第 2 図地表面相対照度の測定位置.

○は株位置, 太は測定位置, 図中数字は距離 $(\mathrm{cm})$ を示す。 狭畦栽培の「株間」は $30 \mathrm{~cm}, 20 \mathrm{~cm}, 15 \mathrm{~cm}, 10 \mathrm{~cm}$ の 4 水 準である。

第 2 表 新潟県農業総合研究所作物研究センター内における月別気象概況.

\begin{tabular}{cccccc}
\hline & 年次 & \multicolumn{1}{c}{6 月 } & \multicolumn{1}{c}{ 月月 } & \multicolumn{1}{c}{8 月 } & 9 月 \\
\hline \multirow{3}{*}{ 日平均気温 } & 2012 & $20.5(99)$ & $24.9(103)$ & $26.9(104)$ & $23.9(111)$ \\
$\left({ }^{\circ} \mathrm{C}^{-1}\right)$ & 2013 & $22.0(107)$ & $24.7(102)$ & $26.0(101)$ & $21.5(100)$ \\
& 2014 & $22.0(107)$ & $24.3(101)$ & $25.3(98)$ & $20.2(94)$ \\
& 平年 & 20.6 & 24.1 & 25.8 & 21.5 \\
\hline 日射量 & 2012 & $549.9(119)$ & $474.5(106)$ & $621.6(126)$ & $460.6(133)$ \\
$\left(\mathrm{MJ} \mathrm{m}^{-2}\right)$ & 2013 & $581.9(126)$ & $402.7(90)$ & $509.1(103)$ & $411.4(119)$ \\
& 2014 & $536.6(116)$ & $491.2(110)$ & $417.1(85)$ & $459.3(133)$ \\
& 平年 & 462.9 & 447.8 & 492.4 & 345.8 \\
\hline \multirow{3}{*}{ 降水量 } & 2012 & $52.5(33)$ & $187.0(71)$ & $56.0(30)$ & $182.0(89)$ \\
$(\mathrm{mm})$ & 2013 & $159.0(99)$ & $426.5(162)$ & $225.5(120)$ & $199.5(97)$ \\
& 2014 & $154.5(97)$ & $213.0(81)$ & $233.5(124)$ & $132.0(64)$ \\
\hline
\end{tabular}

$1981 \sim 2010$ 年の 30 ケ年平均を平年值とした。（）内は平年対比を表す. 
第 3 表 気象庁長岡観測地点における 7〜9月にかけて強い雨または強い風を観測した月日および記録.

\begin{tabular}{|c|c|c|c|c|c|c|c|c|}
\hline \multicolumn{3}{|c|}{2012 年 } & \multicolumn{3}{|c|}{2013 年 } & \multicolumn{3}{|c|}{2014 年 } \\
\hline 観測月日 & $\begin{array}{c}1 \text { 時間雨量 } \\
(\mathrm{mm})\end{array}$ & $\begin{array}{c}\text { 最大瞬間風速 } \\
\left(\mathrm{m} \mathrm{s}^{-1}\right)\end{array}$ & 観測月日 & $\begin{array}{c}1 \text { 時間雨量 } \\
(\mathrm{mm})\end{array}$ & $\begin{array}{c}\text { 最大瞬間風速 } \\
\left(\mathrm{m} \mathrm{s}^{-1}\right)\end{array}$ & 観測月日 & $\begin{array}{c}1 \text { 時間雨量 } \\
(\mathrm{mm})\end{array}$ & $\begin{array}{c}\text { 最大瞬間風速 } \\
\left(\mathrm{m} \mathrm{s}^{-1}\right)\end{array}$ \\
\hline $8 / 6$ & 1.0 & 17.7 & $7 / 17$ & 23.5 & 9.6 & $8 / 22$ & 0.0 & 15.9 \\
\hline $9 / 6$ & 48.5 & 6.1 & $7 / 18$ & 4.5 & 16.1 & $9 / 5$ & 25.0 & 4.6 \\
\hline \multirow[t]{8}{*}{$9 / 30$} & 18.5 & 17.6 & $7 / 29$ & 28.0 & 6.7 & $9 / 16$ & 20.0 & 8.2 \\
\hline & & & $7 / 30$ & 43.5 & 8.2 & & & \\
\hline & & & $8 / 1$ & 31.5 & 6.6 & & & \\
\hline & & & $8 / 24$ & 25.0 & 9.4 & & & \\
\hline & & & $8 / 26$ & 22.5 & 7.0 & & & \\
\hline & & & $8 / 31$ & 18.0 & 16.4 & & & \\
\hline & & & $9 / 2$ & 20.5 & 18.6 & & & \\
\hline & & & $9 / 16$ & 19.5 & 16.4 & & & \\
\hline
\end{tabular}

1 時間雨量 $20 \mathrm{~mm}$ 以上を「強い雨」, 最大瞬間風速 $15 \mathrm{~m} \mathrm{~s}^{-1}$ 以上を「強い風」として列挙した.

日射量は生育期間を通じて平年より高く推移し，降水量は 逆に低く推移した．特に 6 月と 8 月の降水量が平年比 $30 \%$ 台となり，干ばつ傾向の気象条件となった

2013 年は日平均気温が生育期間を通じて概ね平年並みに 推移し，日射量は 6 月および 9 月に高めとなった。降水量 は 7 月に平年比 $162 \%$ と多雨条件となった。この年の 7 月 第 6 半旬は北日本から西日本にかけて短時間に記録的な雨 が降り，所内気象観測地点においても 7 月 29 日から 30 日 にかけて総降水量が $174 \mathrm{~mm}$ となる集中豪雨があった．新 潟県長岡市内のダイズ國場でも約 865 ha の作付面積中, 約 117.5 ha が浸・冠水被害を受けた（長岡市危機管理防災本 部 2014）が，所内ダイズ围場は浸・冠水被害を免れた。

2014 年は日平均気温が 9 月で平年よりやや低かった。 日 射量は 8 月で平年比 $85 \%$ と少なく 9 月は平年比 $133 \%$ と多 かったのに対して，降水量は 8 月で平年比 $124 \%$ と多く 9 月は平年比 $64 \%$ と少なかった。この年の夏場は寡照・多 雨条件であったが，登熟後期は低温ながらも多照条件と なった。

齊藤ら（2012）は岡山県平野部においてダイズの倒伏程 度と台風接近回数には正の相関関係があり，台風の接近に よる降雨と強風が倒伏の主たる要因であることを報告して いる，本研究では降雨・強風と倒伏程度の関係を検討する ため，気象庁で「強い雨」，および「強い風」として定義 している基準值を引用して（気象庁 2015b，c），7９月に 扔ける 1 時間雨量 $20 \mathrm{~mm}$ 以上，または最大瞬間風速 $15 \mathrm{~m}$ $\mathrm{s}^{-1}$ 以上を観測した時期および記録をまとめた結果を第 3 表に示した。 2012 年は 8 月に 1 日，9月に 2 日，豪雨また は強風が観測された，2013 年は前述の集中豪雨を含め，豪 雨または強風の日が多く，7月に 4 日，8月に 4 日，9月 に 2 日の計 10 日観測された。 2014 年は 2012 年同様に, 8 月に 1 日， 9 月に 2 日観測されたが， 1 時間雨量・最大瞬 間風速ともに 2012 年より弱い傾向であった。

\section{2.ダイズの生育および地表面相対 PAR 量の影響}

耕うん同時畧立て狭畦栽培に扔ける「エンレイ」の生育 および相対 PAR 量を第 4 表に示した。試験区の平均值に おいて，播種 30 日後は主茎長が慣行区と比べて狭畦全区 が高く $\mathrm{m}^{2}$ 当り分枝数は慣行区で発生が見られたが，狭 畦全区には見られなかった。相対 PAR 量は慣行区と比べ て狭畦 26.7 株 $\mathrm{m}^{-2}$ 区が低かった，播種 50 日後は主茎長が 慣行区と比べて狭畦 13.3 株 $\mathrm{m}^{-2}$ 区以上が高く，相対 PAR 量は慣行区と比べて狭畦全区が低かった，播種 80 日後は 主茎長が播種 50 日後同様に慣行区と比べて狭畦 13.3 株 $\mathrm{m}^{-2}$ 区以上が高かった。狭畦区内の主茎長の比較では栽植 密度が高くなるほど高くなる傾向となった。

次に,「あやこがね」の生育および相対 PAR 量を第 5 表 に示した。試験区の平均值において，播種 30 日後は主茎 長が慣行区と比べて狭畦全区が高く，相対 PAR 量は慣行 区と比べて狭畦 13.3 株 $\mathrm{m}^{-2}$ 区以上が低く, 狭畦区内の比 較では栽植密度が高くなるほど, 相対 PAR 量は低くなった。 播種 50 日後は主茎長が慣行区と比べて狭畦全区が高く, 狭畦区内の比較では栽植密度が高くなるほど, 主茥長は高 くなった，相対 PAR 量は慣行区と比べて狭畦全区が低かっ た。播種 80 日後は主茎長が慣行区と比べて狭畦 13.3 株 $\mathrm{m}^{-2}$ 区以上が高く，狭畦区内の比較では栽植密度が高くな るほど，主茎長は高くなった。

\section{3. ダイズの成熟期生育および収量性}

「エンレイ」の成熟期生育および収量を第 6 表に示した。 試験区の平均值において，倒伏程度は慣行区と比べて狭畦 17.8 株 $\mathrm{m}^{-2}$ 区以上が高かった。主茎長は慣行区と比べて 狭畦 13.3 株 $\mathrm{m}^{-2}$ 区以上が高く、狭畦区内の比較では栽植 密度が高くなるほど，主茎長は高くなった，茎太は慣行区 と比べて狭畦全区が細く，狭畦区内の比較では栽植密度が 高くなるほど細くなった，株当り分枝数は慣行区と比べて 狭畦 13.3 株 $\mathrm{m}^{-2}$ 区以上が少なく，狭畦区内の比較では栽 
第 4 表 耕うん同時畧立て狭畦栽培の栽植密度の違いが「エンレイ」の生育および地表面の相対 PAR 量に及ぼす影響.

\begin{tabular}{|c|c|c|c|c|c|c|c|c|c|c|}
\hline \multirow[b]{2}{*}{ 年次 } & \multirow[b]{2}{*}{ 試験区 } & \multicolumn{3}{|c|}{ 播種 30 日後 } & \multicolumn{3}{|c|}{ 播種 50 日後 } & \multicolumn{3}{|c|}{ 播種 80 日後 } \\
\hline & & $\begin{array}{c}\text { 主茥長 } \\
(\mathrm{cm})\end{array}$ & $\begin{array}{l}\text { 分枝数 } \\
\left(\text { 本 } \mathrm{m}^{-2}\right)\end{array}$ & $\begin{array}{c}\text { 相対 PAR 量 } \\
(\%)\end{array}$ & $\begin{array}{l}\text { 主茥長 } \\
(\mathrm{cm})\end{array}$ & $\begin{array}{l}\text { 分枝数 } \\
\left(\text { 本 } \mathrm{m}^{-2}\right)\end{array}$ & $\begin{array}{c}\text { 相対 PAR 量 } \\
(\%)\end{array}$ & $\begin{array}{l}\text { 主茥長 } \\
(\mathrm{cm})\end{array}$ & $\begin{array}{l}\text { 分枝数 } \\
\left(\text { 本 } \mathrm{m}^{-2}\right)\end{array}$ & $\begin{array}{c}\text { 相対 PAR 量 } \\
(\%)\end{array}$ \\
\hline \multirow{5}{*}{2012} & 狭畦 8.9 株 $\mathrm{m}^{-2}$ & $15^{\mathrm{a}}$ & 0.0 & 70.2 & $42^{\mathrm{b}}$ & 31.4 & $5.7^{\mathrm{b}}$ & $57^{\mathrm{c}}$ & 46.1 & 3.0 \\
\hline & 狭畦 13.3 株 $\mathrm{m}^{-2}$ & $16^{\mathrm{a}}$ & 0.0 & 80.9 & $46^{\mathrm{b}}$ & 35.5 & $3.4^{\mathrm{b}}$ & $61 \mathrm{bc}$ & 52.1 & 1.2 \\
\hline & 狭畦 17.8 株 $\mathrm{m}^{-2}$ & $16^{\mathrm{a}}$ & 0.0 & 67.4 & $49^{a b}$ & 28.5 & $2.2^{\mathrm{b}}$ & $68^{\mathrm{ab}}$ & 43.9 & 1.2 \\
\hline & 狭畦 26.7 株 $\mathrm{m}^{-2}$ & $16^{\mathrm{a}}$ & 0.0 & 58.1 & $53^{\mathrm{a}}$ & 16.0 & $1.8^{\mathrm{b}}$ & $76^{\mathrm{a}}$ & 43.8 & 1.1 \\
\hline & 慣行 8.9 株 $\mathrm{m}^{-2}$ & $9 \mathrm{~b}$ & 0.0 & 77.4 & $32^{\mathrm{c}}$ & 19.6 & $16.4^{\mathrm{a}}$ & $45^{\mathrm{d}}$ & 41.5 & 2.6 \\
\hline \multirow{5}{*}{2013} & 狭畦 8.9 株 $\mathrm{m}^{-2}$ & $23^{a b}$ & 0.0 & $63.8^{\mathrm{a}}$ & $43 \mathrm{~b}$ & 18.7 & $17.2^{\mathrm{a}}$ & $46^{\mathrm{c}}$ & $36.7^{\mathrm{a}}$ & 3.2 \\
\hline & 狭畦 13.3 株 $\mathrm{m}^{-2}$ & $24^{\mathrm{a}}$ & 0.0 & $49.3^{\mathrm{ab}}$ & $53^{\mathrm{a}}$ & 20.4 & $7.0^{\mathrm{b}}$ & $57^{\mathrm{ab}}$ & $40.2^{\mathrm{a}}$ & 1.6 \\
\hline & 狭畦 17.8 株 $\mathrm{m}^{-2}$ & $25^{\mathrm{a}}$ & 0.0 & $44.2^{\mathrm{ab}}$ & $53^{\mathrm{a}}$ & 12.5 & $5.6^{\mathrm{b}}$ & $63^{\mathrm{a}}$ & $28.1^{\mathrm{a}}$ & 1.5 \\
\hline & 狭畦 26.7 株 $\mathrm{m}^{-2}$ & $24^{\mathrm{a}}$ & 0.0 & $38.7^{\mathrm{b}}$ & $53^{\mathrm{a}}$ & 2.7 & $5.4^{b}$ & $65^{\mathrm{a}}$ & $8.2^{\mathrm{b}}$ & 2.1 \\
\hline & 慣行 8.9 株 $\mathrm{m}^{-2}$ & $22^{\mathrm{b}}$ & 1.8 & $52.4^{\mathrm{ab}}$ & $46^{\mathrm{ab}}$ & 20.5 & $22.1^{\mathrm{a}}$ & $52 \mathrm{bc}$ & $28.8^{\mathrm{a}}$ & 2.3 \\
\hline \multirow{5}{*}{2014} & 狭畦 8.9 株 $\mathrm{m}^{-2}$ & $21^{\mathrm{a}}$ & 0.0 & $69.2^{\mathrm{a}}$ & $47^{\mathrm{b}}$ & 24.3 & $5.7^{\mathrm{b}}$ & $57^{\mathrm{c}}$ & $36.2^{b}$ & 1.5 \\
\hline & 狭畦 13.3 株 $\mathrm{m}^{-2}$ & $23^{\mathrm{a}}$ & 0.0 & $50.0^{\mathrm{ab}}$ & $57^{\mathrm{a}}$ & 28.4 & $2.5^{\mathrm{b}}$ & $67^{\mathrm{b}}$ & $50.5^{\mathrm{ab}}$ & 0.7 \\
\hline & 狭畦 17.8 株 $\mathrm{m}^{-2}$ & $23^{\mathrm{a}}$ & 0.0 & $51.5^{\mathrm{ab}}$ & $57^{\mathrm{a}}$ & 36.8 & $1.6^{\mathrm{b}}$ & $67^{\mathrm{b}}$ & $59.3^{\mathrm{a}}$ & 1.0 \\
\hline & 狭畦 26.7 株 $\mathrm{m}^{-2}$ & $22^{\mathrm{a}}$ & 0.0 & $34.2^{\mathrm{b}}$ & $60^{\mathrm{a}}$ & 32.0 & $1.1^{\mathrm{b}}$ & $76^{\mathrm{a}}$ & $53.4^{\mathrm{ab}}$ & 1.4 \\
\hline & 慣行 8.9 株 $\mathrm{m}^{-2}$ & $17^{\mathrm{b}}$ & 0.6 & $60.4^{\mathrm{a}}$ & $47^{\mathrm{b}}$ & 30.9 & $12.3^{\mathrm{a}}$ & $56^{\mathrm{c}}$ & $46.3^{\mathrm{ab}}$ & 0.9 \\
\hline \multirow{8}{*}{ 平均 } & 2012 & $14^{\mathrm{c}}$ & 0.0 & $70.8^{a}$ & $44^{c}$ & $26.2^{\mathrm{a}}$ & $5.9^{\mathrm{b}}$ & $62^{\mathrm{a}}$ & $45.5^{\mathrm{a}}$ & $1.9^{\mathrm{ab}}$ \\
\hline & 2013 & $23^{\mathrm{a}}$ & 0.4 & $49.7^{\mathrm{b}}$ & $50^{b}$ & $14.9^{b}$ & $11.5^{\mathrm{a}}$ & $57^{\mathrm{b}}$ & $28.4^{\mathrm{b}}$ & $2.1^{\mathrm{a}}$ \\
\hline & 2014 & $21 \mathrm{~b}$ & 0.1 & $53.1^{\mathrm{b}}$ & $54^{\mathrm{a}}$ & $30.5^{\mathrm{a}}$ & $4.6^{\mathrm{b}}$ & $64^{\mathrm{a}}$ & $49.1^{\mathrm{a}}$ & $1.1^{\mathrm{b}}$ \\
\hline & 狭畦 8.9 株 $\mathrm{m}^{-2}$ & $20^{\mathrm{b}}$ & $0.0^{\mathrm{b}}$ & $67.7^{\mathrm{a}}$ & $44^{\mathrm{b}}$ & 24.8 & $9.5^{\mathrm{b}}$ & $53^{c}$ & $39.7^{\mathrm{ab}}$ & 2.6 \\
\hline & 狭畦 13.3 株 $\mathrm{m}^{-2}$ & $21^{\mathrm{a}}$ & $0.0^{\mathrm{b}}$ & $60.1^{\mathrm{a}}$ & $52^{\mathrm{a}}$ & 28.1 & $4.3^{\mathrm{c}}$ & $62^{\mathrm{b}}$ & $47.6^{\mathrm{a}}$ & 1.2 \\
\hline & 狭畦 17.8 株 $\mathrm{m}^{-2}$ & $21^{\mathrm{a}}$ & $0.0^{\mathrm{b}}$ & $54.4^{\mathrm{ab}}$ & $53^{\mathrm{a}}$ & 25.9 & $3.1^{\mathrm{c}}$ & $66^{\mathrm{b}}$ & $43.8^{a b}$ & 1.2 \\
\hline & 狭畦 26.7 株 $\mathrm{m}^{-2}$ & $21^{\mathrm{a}}$ & $0.0 \mathrm{~b}$ & $43.7^{b}$ & $56^{\mathrm{a}}$ & 16.9 & $2.8^{\mathrm{c}}$ & $72^{\mathrm{a}}$ & $35.2^{b}$ & 1.5 \\
\hline & 慣行 8.9 株 $\mathrm{m}^{-2}$ & $16^{\mathrm{c}}$ & $0.8^{\mathrm{a}}$ & $63.4^{\mathrm{a}}$ & $42^{\mathrm{b}}$ & 23.6 & $16.9^{\mathrm{a}}$ & $51^{c}$ & $38.9^{\mathrm{ab}}$ & 2.0 \\
\hline \multirow{3}{*}{$\begin{array}{l}\text { 分散 } \\
\text { 分析 }\end{array}$} & 年次 (A) & $* *$ & ns & $* *$ & $* *$ & $* *$ & $* *$ & $* *$ & $* *$ & $*$ \\
\hline & 試験区 (B) & $* *$ & $*$ & $* *$ & $* *$ & ns & $* *$ & $* *$ & $*$ & ns \\
\hline & $\mathrm{A} \times \mathrm{B}$ & $* *$ & ns & ns & $*$ & ns & ns & $*$ & $* *$ & ns \\
\hline
\end{tabular}

分散分析の**＊はそれぞれ $1 \% ， 5 \%$ 水準で有意差あり，ns は有意差なしを示す，異なる英文字間は年次別，拈よび平均では要因別に $5 \%$ 水 準で有意差ありを示す (Tukey 法).

植密度が高くなるほど少なくなった，最下着萊節位高は慣 行区と比べて狭畦全区が高かった，m 2 当り有効萊数は慣 行区と比べて狭畦 26.7 株 $\mathrm{m}^{-2}$ 区が多かった。百粒重は試 験区間で差が見られず，収量は慣行区と比べて狭畦 17.8 株 $\mathrm{m}^{-2}$ 区以上が多かった。

次に,「あやこがね」の成熟期生育および収量を第 7 表 に示した，試験区の平均值において，倒伏程度は「エンレ イ」とは異なり，試験区間で差が見られなかった。主茎長 は慣行区と比べて狭畦 13.3 株 $\mathrm{m}^{-2}$ 区以上が高く, 狭畦区 内の比較では栽植密度が高くなるほど, 主茥長は高くなっ た．茎太は慣行区と比べて狭畦 13.3 株 $\mathrm{m}^{-2}$ 区以上が細く, 狭畦区内の比較では栽植密度が高くなるほど細くなった。 株当り分枝数は慣行区と比べて狭畦 17.8 株 $\mathrm{m}^{-2}$ 区以上が 少なく, 狭畦区内の比較では栽植密度が高くなるほど少な くなった，最下着萊節位高は慣行区と比べて狭畦 13.3 株 $\mathrm{m}^{-2}$ 区以上が高く, $\mathrm{m}^{2}$ 当り有効萊数も慣行区と比べて狭畦 13.3 株 $\mathrm{m}^{-2}$ 区以上が多かった。百粒重は試験区間で差が
見られず，収量は慣行区と比べて狭畦 13.3 株 $\mathrm{m}^{-2}$ 区以上 が多かった。

\section{考察}

\section{1.ダイズの地表面相対 PAR 量の影響}

播種 30 日後におけるダイズ群落内の 3 ケ年平均の相対 PAR 量を見ると（第 4 表，第 5 表)，「エンレイ」では慣行 区より有意に低くなったのは狭畦 26.7 株 $\mathrm{m}^{-2}$ 区であり,「あ やこがね」では狭畦 13.3 株 $\mathrm{m}^{-2}$ 区以上となった，両品種 に扔ける生育の違いをみると, 主茎長では慣行区と狭畦区 の差が両品種とも 4 $5 \mathrm{~cm}$ 程度で品種間の違いは見られな かった. 次に $\mathrm{m}^{2}$ 当たり分枝数では,「エンレイ」が狭畦区 で分枝の発生が見られず，慣行区は分枝が発生したのに対 して，「あやこがね」は狭畦区で分枝の発生が見られ，慣 行区との分枝数の差は見られなかった，この時期の一次分 枝の節数は 2 節程度と少ないが，「あやこがね」のように 分枝数を確保することが，狭畦区が慣行区よりも被覆力を 
第 5 表 耕うん同時畧立て狭畦栽培の栽植密度の違いが「あやこがね」の生育および地表面の相対 PAR 量に及ぼす影響.

\begin{tabular}{|c|c|c|c|c|c|c|c|c|c|c|}
\hline \multirow[b]{2}{*}{ 年次 } & \multirow[b]{2}{*}{ 試験区 } & \multicolumn{3}{|c|}{ 播種 30 日後 } & \multicolumn{3}{|c|}{ 播種 50 日後 } & \multicolumn{3}{|c|}{ 播種 80 日後 } \\
\hline & & $\begin{array}{c}\text { 主茥長 } \\
(\mathrm{cm})\end{array}$ & $\begin{array}{l}\text { 分枝数 } \\
\left(\text { 本 } \mathrm{m}^{-2}\right)\end{array}$ & $\begin{array}{c}\text { 相対 PAR 量 } \\
(\%)\end{array}$ & $\begin{array}{c}\text { 主茎長 } \\
(\mathrm{cm})\end{array}$ & $\begin{array}{l}\text { 分枝数 } \\
\left(\text { 本 } \mathrm{m}^{-2}\right)\end{array}$ & $\begin{array}{c}\text { 相対 PAR 量 } \\
(\%)\end{array}$ & $\begin{array}{c}\text { 主茎長 } \\
(\mathrm{cm})\end{array}$ & $\begin{array}{l}\text { 分枝数 } \\
\left(\text { 本 } \mathrm{m}^{-2}\right)\end{array}$ & $\begin{array}{c}\text { 相対 PAR 量 } \\
(\%)\end{array}$ \\
\hline \multirow{5}{*}{2012} & 狭畦 8.9 株 $\mathrm{m}^{-2}$ & $14^{\mathrm{a}}$ & 0.0 & $84.8^{\mathrm{ab}}$ & $43^{b}$ & $38.0^{\mathrm{a}}$ & $5.0 \mathrm{~b}$ & $59 \mathrm{bc}$ & 54.6 & 1.8 \\
\hline & 狭畦 13.3 株 $\mathrm{m}^{-2}$ & $14^{\mathrm{a}}$ & 0.0 & $84.6^{\mathrm{ab}}$ & $49 \mathrm{ab}$ & $39.0^{\mathrm{a}}$ & $2.0^{\mathrm{b}}$ & $70 \mathrm{ab}$ & 61.2 & 1.4 \\
\hline & 狭畦 17.8 株 $\mathrm{m}^{-2}$ & $15^{\mathrm{a}}$ & 0.0 & $68.6 \mathrm{bc}$ & $50^{a b}$ & $32.0 \mathrm{ab}$ & $1.3^{b}$ & $73^{a b}$ & 62.2 & 1.0 \\
\hline & 狭畦 26.7 株 $\mathrm{m}^{-2}$ & $15^{\mathrm{a}}$ & 0.0 & $60.7^{\mathrm{c}}$ & $58^{\mathrm{a}}$ & $21.4^{b}$ & $1.1^{\mathrm{b}}$ & $80^{\mathrm{a}}$ & 60.3 & 2.8 \\
\hline & 慣行 8.9 株 $\mathrm{m}^{-2}$ & $8^{b}$ & 0.0 & $95.2^{\mathrm{a}}$ & $28^{\mathrm{c}}$ & $24.3^{\mathrm{ab}}$ & $16.7^{\mathrm{a}}$ & $44^{c}$ & 46.6 & 1.1 \\
\hline \multirow{5}{*}{2013} & 狭畦 8.9 株 $\mathrm{m}^{-2}$ & $20^{\mathrm{b}}$ & 0.0 & $63.6^{\mathrm{a}}$ & $42^{\mathrm{b}}$ & $18.1^{\mathrm{ab}}$ & $13.0^{\mathrm{ab}}$ & $49 \mathrm{~b}$ & 37.0 & $2.6^{a b}$ \\
\hline & 狭畦 13.3 株 $\mathrm{m}^{-2}$ & $21^{\mathrm{ab}}$ & 0.0 & $51.9^{a b}$ & $49^{a b}$ & $21.3^{\mathrm{ab}}$ & $7.9 \mathrm{bc}$ & $60 \mathrm{ab}$ & 36.1 & $1.3^{b}$ \\
\hline & 狭畦 17.8 株 $\mathrm{m}^{-2}$ & $22^{\mathrm{ab}}$ & 1.2 & $50.6^{\mathrm{ab}}$ & $53^{\mathrm{a}}$ & $11.3^{b c}$ & $7.8 \mathrm{bc}$ & $68^{\mathrm{a}}$ & 28.1 & $1.3^{b}$ \\
\hline & 狭畦 26.7 株 $\mathrm{m}^{-2}$ & $23^{\mathrm{a}}$ & 0.0 & $34.8^{b}$ & $55^{\mathrm{a}}$ & $0.0^{\mathrm{c}}$ & $4.6^{\mathrm{c}}$ & $71^{\mathrm{a}}$ & 18.3 & $1.3^{b}$ \\
\hline & 慣行 8.9 株 $\mathrm{m}^{-2}$ & $21 \mathrm{ab}$ & 3.6 & $55.6^{\mathrm{a}}$ & $47 \mathrm{ab}$ & $27.3^{\mathrm{a}}$ & $18.8^{\mathrm{a}}$ & 56 ab & 33.2 & $3.6^{\mathrm{a}}$ \\
\hline \multirow{5}{*}{2014} & 狭畦 8.9 株 $\mathrm{m}^{-2}$ & $20^{\mathrm{a}}$ & 1.8 & $63.2^{\mathrm{ab}}$ & $48 \mathrm{bc}$ & 30.9 & $4.8^{b}$ & $59 \mathrm{bc}$ & 42.7 & 1.6 \\
\hline & 狭畦 13.3 株 $\mathrm{m}^{-2}$ & $20^{\mathrm{a}}$ & 2.7 & $48.2 \mathrm{bc}$ & $57 \mathrm{ab}$ & 33.7 & $1.3^{b}$ & $72^{a b}$ & 47.9 & 1.0 \\
\hline & 狭畦 17.8 株 $\mathrm{m}^{-2}$ & $21^{\mathrm{a}}$ & 2.4 & $37.4^{\mathrm{c}}$ & $60^{\mathrm{a}}$ & 39.2 & $1.6^{\mathrm{b}}$ & $72^{a b}$ & 61.7 & 1.7 \\
\hline & 狭畦 26.7 株 $\mathrm{m}^{-2}$ & $21^{\mathrm{a}}$ & 1.8 & $31.1^{\mathrm{c}}$ & $63^{\mathrm{a}}$ & 40.9 & $1.2^{\mathrm{b}}$ & $81^{\mathrm{a}}$ & 51.6 & 1.0 \\
\hline & 慣行 8.9 株 $\mathrm{m}^{-2}$ & $13^{b}$ & 0.0 & $70.7^{\mathrm{a}}$ & $40^{\mathrm{c}}$ & 29.7 & $11.2^{\mathrm{a}}$ & $53^{c}$ & 46.3 & 1.1 \\
\hline \multirow{8}{*}{ 平均 } & 2012 & $13^{c}$ & 0.0 & $78.8^{a}$ & $46^{\mathrm{b}}$ & $30.9^{a}$ & $5.2^{\mathrm{b}}$ & $65^{\mathrm{ab}}$ & $57.0^{\mathrm{a}}$ & $1.6^{\mathrm{ab}}$ \\
\hline & 2013 & $21^{\mathrm{a}}$ & 0.9 & $51.3^{b}$ & $49 \mathrm{~b}$ & $15.6^{\mathrm{b}}$ & $10.4^{\mathrm{a}}$ & $61^{\mathrm{b}}$ & $30.5^{b}$ & $2.0^{\mathrm{a}}$ \\
\hline & 2014 & $19 \mathrm{~b}$ & 1.7 & $50.1^{\mathrm{b}}$ & $54^{\mathrm{a}}$ & $34.9^{\mathrm{a}}$ & $4.0^{\mathrm{b}}$ & $67^{\mathrm{a}}$ & $50.0^{\mathrm{a}}$ & $1.3^{b}$ \\
\hline & 狭畦 8.9 株 $\mathrm{m}^{-2}$ & $18^{b}$ & 0.6 & $70.5^{\mathrm{ab}}$ & $44^{\mathrm{c}}$ & 29.0 ab & $7.6^{b}$ & $56^{c}$ & 44.8 & 2.0 \\
\hline & 狭畦 13.3 株 $\mathrm{m}^{-2}$ & $19^{a b}$ & 0.9 & $61.6 \mathrm{bc}$ & $52^{b}$ & $31.3^{\mathrm{a}}$ & $3.7^{\mathrm{c}}$ & $67 \mathrm{~b}$ & 48.4 & 1.2 \\
\hline & 狭畦 17.8 株 $\mathrm{m}^{-2}$ & $19^{\mathrm{ab}}$ & 1.2 & $52.2^{\mathrm{cd}}$ & $55^{a b}$ & $27.5^{\mathrm{ab}}$ & $3.6^{\mathrm{c}}$ & $71^{\mathrm{ab}}$ & 50.7 & 1.4 \\
\hline & 狭畦 26.7 株 $\mathrm{m}^{-2}$ & $20^{\mathrm{a}}$ & 0.6 & $42.2^{\mathrm{d}}$ & $58^{\mathrm{a}}$ & $20.8^{b}$ & $2.3^{\mathrm{c}}$ & $77^{\mathrm{a}}$ & 43.4 & 1.7 \\
\hline & 慣行 8.9 株 $\mathrm{m}^{-2}$ & $14^{\mathrm{c}}$ & 1.2 & $73.8^{\mathrm{a}}$ & $39^{\mathrm{d}}$ & $27.1^{\mathrm{ab}}$ & $15.6^{\mathrm{a}}$ & $51^{c}$ & 42.0 & 1.9 \\
\hline \multirow{3}{*}{$\begin{array}{l}\text { 分散 } \\
\text { 分析 }\end{array}$} & 年次 (A) & $* *$ & ns & $* *$ & $* *$ & $* *$ & $* *$ & $*$ & $* *$ & $*$ \\
\hline & 試験区 (B) & $* *$ & ns & $* *$ & $* *$ & $*$ & $* *$ & $* *$ & ns & ns \\
\hline & $\mathrm{A} \times \mathrm{B}$ & $* *$ & ns & ns & $* *$ & $* *$ & ns & ns & ns & $* *$ \\
\hline
\end{tabular}

分散分析の**，*はそれぞれ $1 \% ， 5 \%$ 水準で有意差あり，ns は有意差なしを示す，異なる英文字間は年次別，および平均では要因別に $5 \%$ 水 準で有意差ありを示す (Tukey 法)。

高める上で重要であることが考えられた，狭畦区内におけ る栽植密度毎の 3 ケ年平均の相対 PAR 量を見ると, 両品 種とも密度が高くなると相対 PAR 量は低くなる傾向が見 られた。狭畦 13.3 株 $\mathrm{m}^{-2}$ 区と狭畦 26.7 株 $\mathrm{m}^{-2}$ 区を比較 すると，両品種とも主茎長と分枝数には差が見られないも のの, 相対 PAR 量は狭畦 26.7 株 $\mathrm{m}^{-2}$ 区の方が低くなった.

播種 50 日後における 3 ケ年平均の相対 PAR 量では, 両 品種とも狭畦区が慣行区より低く，被覆力は狭畦栽培の方 が高いことが伺えた，生育の違いをみると，主茎長が「工 ンレイ」では狭畦 13.3 株 $\mathrm{m}^{-2}$ 区以上で慣行区より長く,「あ やこがね」では全ての狭畦区が慣行区より長かった． $\mathrm{m}^{2}$ 当たり分枝数では両品種とも狭畦区と慣行区の間に差はな かった，播種 50 日後の時期は主茎の伸長が相対 PAR 量を 低くする一因になると想定できるが，一方で「エンレイ」 の狭畦 8.9 株 $\mathrm{m}^{-2}$ 区と慣行区のように，栽植密度に差がな く，かつ主茎長扔よび分枝数も有意差が見られなくても， 相対 PAR 量は狭畦区が有意に低くなっている，年次別で
も 2012，2014 年の「エンレイ」および「あやこがね」で 同様の傾向が見られた，前報において，同じ播種密度条件 でも，畧立て狭畦栽培は条間 $37 \mathrm{~cm}$ （平均条間 $40 \mathrm{~cm}$ ）の 株間 $16 \mathrm{~cm}$, 慣行栽培は条間 $80 \mathrm{~cm}$ の株間 $8 \mathrm{~cm}$ と, 慣行栽 培と比べて狭畦栽培は条間が $43 \mathrm{~cm}$ も狭まるのに対して, 株間は $8 \mathrm{~cm}$ 程度しか広がらないことから, 狭畦栽培の方 がダイズ間の光の競合が起きやすい可能性があることを報 告した（藤田ら 2014）。また中野ら（2001）は, ダイズの 正方形播きは長方形播きに比へ，群落が早期に密閉状態に なること，また，葉面積が数值的に大きくなり，ダイズ品 種によっては有意な差が現れたことを報告している。狭畦 8.9 株 $\mathrm{m}^{-2}$ 区の平高畧上の配列は条間 $32 \mathrm{~cm}$, 株間 $30 \mathrm{~cm}$ とほぼ正方形の配列となっており，このことから，本研究 では播種 50 日後の狭畦区と慣行区で栽植密度やダイズ株 の主茎長打よび分枝数に違いがなくても, 狭畦区は葉の重 なりによる密閉状態が早期に確保でき, 相対 PAR 量は狭 畦区の方が低くなったものと考えられた，狭畦区における 
第 6 表 耕うん同時畧立て狭畦栽培の栽植密度の違いが「エンレイ」の成熟期生育および収量に及ぼす影響

\begin{tabular}{|c|c|c|c|c|c|c|c|c|c|c|}
\hline \multirow{3}{*}{ 年次 } & \multirow{3}{*}{ 試験区 } & \multirow{3}{*}{$\begin{array}{c}\text { 倒伏程度 } \\
(0-5)\end{array}$} & \multirow{3}{*}{$\begin{array}{c}\text { 主茥長 } \\
(\mathrm{cm})\end{array}$} & \multirow{3}{*}{$\begin{array}{l}\text { 茎太 } \\
(\mathrm{mm})\end{array}$} & \multicolumn{2}{|c|}{ 分枝数 } & \multirow{3}{*}{$\begin{array}{c}\text { 最下着萊 } \\
\text { 節位高 } \\
(\mathrm{cm})\end{array}$} & \multirow{3}{*}{$\begin{array}{c}\mathrm{m}^{2} \text { 当り } \\
\text { 有効萊数 } \\
\text { (莢) }\end{array}$} & \multirow{3}{*}{$\begin{array}{c}\text { 百粒重 } \\
(\mathrm{g})\end{array}$} & \multirow{3}{*}{$\begin{array}{l}\text { 収量 } \\
\left(\mathrm{g} \mathrm{m}^{-2}\right)\end{array}$} \\
\hline & & & & & 株当り & $\mathrm{m}^{2}$ 当り & & & & \\
\hline & & & & & (本) & (本) & & & & \\
\hline \multirow[t]{5}{*}{2012} & 狭畦 8.9 株 $\mathrm{m}^{-2}$ & 3.0 & $55^{\mathrm{cd}}$ & $7.5^{\mathrm{ab}}$ & $5.3^{\mathrm{a}}$ & 47.5 & $15.6^{\mathrm{a}}$ & 578 & 29.2 & 286 \\
\hline & 狭畦 13.3 株 $\mathrm{m}^{-2}$ & 3.2 & $61 \mathrm{bc}$ & $7.4^{\mathrm{ab}}$ & $4.1^{\mathrm{ab}}$ & 54.1 & $16.1^{\mathrm{a}}$ & 621 & 27.9 & 302 \\
\hline & 狭畦 17.8 株 $\mathrm{m}^{-2}$ & 3.7 & $66^{\mathrm{ab}}$ & $6.9^{\mathrm{b}}$ & $3.1^{\mathrm{bc}}$ & 55.8 & $15.9^{\mathrm{a}}$ & 674 & 29.0 & 333 \\
\hline & 狭畦 26.7 株 $\mathrm{m}^{-2}$ & 3.5 & $74^{\mathrm{a}}$ & $5.8^{\mathrm{c}}$ & $1.6^{\mathrm{c}}$ & 42.7 & $19.3^{\mathrm{a}}$ & 715 & 28.6 & 343 \\
\hline & 慣行 8.9 株 $\mathrm{m}^{-2}$ & 0.0 & $46^{\mathrm{d}}$ & $7.9^{\mathrm{a}}$ & $4.5^{\mathrm{ab}}$ & 39.8 & $9.4^{\mathrm{b}}$ & 614 & 28.9 & 314 \\
\hline \multirow[t]{5}{*}{2013} & 狭畦 8.9 株 $\mathrm{m}^{-2}$ & 0.3 & $45 \mathrm{~b}$ & $6.7 \mathrm{ab}$ & $4.4^{\mathrm{a}}$ & 39.2 & $15.7^{\mathrm{b}}$ & 462 & $31.5^{\mathrm{a}}$ & $251^{\mathrm{ab}}$ \\
\hline & 狭畦 13.3 株 $\mathrm{m}^{-2}$ & 1.0 & $56^{\mathrm{ab}}$ & $6.2^{b c}$ & $2.9^{\mathrm{ab}}$ & 38.1 & $21.7^{\mathrm{a}}$ & 540 & $31.2^{\mathrm{a}}$ & $290^{\mathrm{a}}$ \\
\hline & 狭畦 17.8 株 $\mathrm{m}^{-2}$ & 0.7 & $60^{\mathrm{a}}$ & $5.8^{\mathrm{c}}$ & $2.0 \mathrm{bc}$ & 35.6 & $26.6^{\mathrm{a}}$ & 576 & $31.6^{\mathrm{a}}$ & $302^{\mathrm{a}}$ \\
\hline & 狭畦 26.7 株 $\mathrm{m}^{-2}$ & 1.3 & $63^{\mathrm{a}}$ & $5.5^{\mathrm{c}}$ & $0.8^{\mathrm{c}}$ & 21.4 & $26.6^{\mathrm{a}}$ & 610 & $31.8^{\mathrm{a}}$ & $301^{\mathrm{a}}$ \\
\hline & 慣行 8.9 株 $\mathrm{m}^{-2}$ & 0.0 & $48^{b}$ & $7.2^{\mathrm{a}}$ & $3.7^{\mathrm{a}}$ & 33.2 & $13.1^{b}$ & 557 & $29.0^{\mathrm{b}}$ & $222^{b}$ \\
\hline \multirow[t]{5}{*}{2014} & 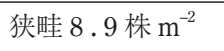 & 1.0 & $57^{c}$ & $7.1^{\mathrm{b}}$ & $4.8^{\mathrm{ab}}$ & 42.7 & $16.9 \mathrm{bc}$ & $646^{\mathrm{ab}}$ & 36.3 & $370^{b}$ \\
\hline & 狭畦 13.3 株 $\mathrm{m}^{-2}$ & 0.7 & $67 \mathrm{~b}$ & $6.6 \mathrm{bc}$ & $4.3^{\mathrm{b}}$ & 56.7 & $21.8^{\mathrm{ab}}$ & $742^{a b}$ & 36.5 & $426^{\mathrm{ab}}$ \\
\hline & 狭畦 17.8 株 $\mathrm{m}^{-2}$ & 2.0 & $69^{a b}$ & $7.0^{\mathrm{b}}$ & $3.6^{\mathrm{bc}}$ & 64.1 & $22.6^{\mathrm{a}}$ & $681 \mathrm{ab}$ & 36.4 & $420^{\mathrm{ab}}$ \\
\hline & 狭畦 26.7 株 $\mathrm{m}^{-2}$ & 1.3 & $78^{a}$ & $6.1^{\mathrm{c}}$ & $2.4^{\mathrm{c}}$ & 65.0 & $21.4^{\mathrm{ab}}$ & $789^{\mathrm{a}}$ & 37.0 & $459^{\mathrm{a}}$ \\
\hline & 慣行 8.9 株 $\mathrm{m}^{-2}$ & 1.0 & $56^{c}$ & $8.4^{\mathrm{a}}$ & $5.9^{\mathrm{a}}$ & 52.8 & $13.7^{\mathrm{c}}$ & $628^{\mathrm{b}}$ & 36.8 & $384^{b}$ \\
\hline \multirow[t]{11}{*}{ 平均 } & 2012 & $2.7^{\mathrm{a}}$ & $60^{b}$ & $7.1^{\mathrm{a}}$ & $3.7^{\mathrm{a}}$ & $48.0^{\mathrm{a}}$ & $15.3^{b}$ & $640^{\mathrm{a}}$ & $28.7^{\mathrm{c}}$ & $316^{b}$ \\
\hline & 2013 & $0.7^{\mathrm{b}}$ & $55^{c}$ & $6.3^{\mathrm{b}}$ & $2.8^{\mathrm{b}}$ & $33.5^{\mathrm{b}}$ & $20.7^{\mathrm{a}}$ & $549 \mathrm{~b}$ & $31.0^{\mathrm{b}}$ & $273^{c}$ \\
\hline & 2014 & $1.2^{b}$ & $65^{\mathrm{a}}$ & $7.0^{\mathrm{a}}$ & $4.2^{\mathrm{a}}$ & $56.3^{\mathrm{a}}$ & $19.3^{\mathrm{a}}$ & $697^{\mathrm{a}}$ & $36.6^{\mathrm{a}}$ & $412^{\mathrm{a}}$ \\
\hline & 狭畦 8.9 株 $\mathrm{m}^{-2}$ & $1.4^{\mathrm{ab}}$ & $52^{\mathrm{c}}$ & $7.1^{\mathrm{b}}$ & $4.8^{\mathrm{a}}$ & 43.1 & $16.0^{\mathrm{b}}$ & $562^{b}$ & 32.3 & $303^{b}$ \\
\hline & 狭畦 13.3 株 $\mathrm{m}^{-2}$ & $1.6^{\mathrm{ab}}$ & $61^{\mathrm{b}}$ & $6.7 \mathrm{bc}$ & $3.7^{\mathrm{b}}$ & 49.7 & $19.8^{\mathrm{a}}$ & $634^{\mathrm{ab}}$ & 31.9 & $339 \mathrm{ab}$ \\
\hline & 狭畦 17.8 株 $\mathrm{m}^{-2}$ & $2.1^{\mathrm{a}}$ & $65^{b}$ & $6.6^{\mathrm{c}}$ & $2.9^{b}$ & 51.8 & $21.7^{\mathrm{a}}$ & $644^{\mathrm{ab}}$ & 32.3 & $352^{\text {a }}$ \\
\hline & 狭畦 26.7 株 $\mathrm{m}^{-2}$ & $2.1^{\mathrm{a}}$ & $71^{\mathrm{a}}$ & $5.8^{\mathrm{d}}$ & $1.6^{\mathrm{c}}$ & 43.0 & $22.4^{\mathrm{a}}$ & $704^{\mathrm{a}}$ & 32.5 & $368^{\mathrm{a}}$ \\
\hline & 慣行 8.9 株 $\mathrm{m}^{-2}$ & $0.3^{\mathrm{b}}$ & $50^{c}$ & $7.8^{\mathrm{a}}$ & $4.7^{\mathrm{a}}$ & 41.9 & $12.1^{\mathrm{c}}$ & $600^{\mathrm{b}}$ & 31.6 & $307^{\mathrm{b}}$ \\
\hline & 年次 (A) & $* *$ & $* *$ & $* *$ & $* *$ & $* *$ & $* *$ & $* *$ & $* *$ & $* *$ \\
\hline & 試験区（B） & $*$ & $* *$ & $* *$ & $* *$ & ns & $* *$ & $* *$ & ns & $* *$ \\
\hline & $\mathrm{A} \times \mathrm{B}$ & - & ns & $*$ & ns & ns & $*$ & ns & $*$ & ns \\
\hline
\end{tabular}

倒伏程度は 0 ：無，1：微，2：少，3：中，4：多，5：甚，を表す。**＊はそれぞれ 1\%，5\%水準で有意差あり，nsは有意差なしを示す（倒 伏程度：Kruskal-Wallis 検定, 他項目：分散分析法)。異なる英文字間は年次別, および平均では要因別に $5 \%$ 水準で有意差ありを示す（倒伏 程度：Steel-Dwass 法, 他項目：Tukey 法)

栽植密度毎の 3 ケ年平均の相対 PAR 量を見ると, 両品種 とも狭畦 8.9 株 $\mathrm{m}^{-2}$ 区が狭畦 13.3 株 $\mathrm{m}^{-2}$ 区以上より高く, やや被覆力が劣った. しかし相対 PAR 量は $10 \%$ 以下と, 雑草を抑制する值（野口・中山 1978）となり，抑草効果は ほぼ同等であると考えられた。達観による調査であるが, 雑草発生量は両品種のいずれの試験区もほとんど皆無に等 しかった (デー夕省略)。ただし，2013 年の試験のように 狭畦 8.9 株 $\mathrm{m}^{-2}$ 区では相対 PAR 量が $10 \%$ を上回る事例も ある。この年は「エンレイ」，「あやこがね」ともに $\mathrm{m}^{2}$ 当 たり分枝数が他の年次よりも少なく, 狭畦 26.7 株 $\mathrm{m}^{-2}$ 区 では 0 3 本程度しか発生しなかった。 2013 年の 7 月 1 日 から播種 50 日後の調査前日に当たる 7 月 25 日までの気象 状況は, 総日射量は $308.5 \mathrm{MJ} \mathrm{m}^{-2}$ と低く, 総降水量は 233 $\mathrm{ml}$ と多く, 7 月 29〜30 日にかけての大雨以前にも, 量天 で雨の多い日が続いた，大泉（1962）は日射制限が大きい ほど分枝の発生が少なくなること，また古畑ら（2011）は
北陸地域の粘質土壤における過湿状態で分枝数の増加が抑 制されたことを報告していることから，2013 年の寡照多雨 条件が分枝数の発生を抑制したものと推察された。このよ うに狭畦栽培でも年次によってはダイズの生育停滞によっ て被覆力が弱まり, 雑草害を引き起こすことも考えられる. 狭畦栽培においても株間が広い条件では, 茎葉処理除草剤 の適期散布の徹底など，相対 PAR 量が慣行区も含めて確 実に $10 \%$ 以下となる播種 80 日後までは雑草を繁茂させな い管理が必要であることが伺えた。

\section{2. ダイズの成熟期生育および収量}

畧立て狭畦栽培における成熟期のダイズ生育は（第 6 表, 第 7 表)，主菱長では「エンレイ」，「あやこがね」両品種 ともに, 各年次および 3 ケ年平均で栽植密度が高くなるほ ど高くなる傾向となった，茎太では「エンレイ」は 2012 , 2013 年と 3 ケ年平均で,「あやこがね」では各年次および 3 ケ 
第 7 表 耕うん同時畧立て狭畦栽培の栽植密度の違いが「あやこがね」の成熟期生育および収量に及ぼす影響.

\begin{tabular}{|c|c|c|c|c|c|c|c|c|c|c|}
\hline \multirow{3}{*}{ 年次 } & \multirow{3}{*}{ 試験区 } & \multirow{3}{*}{$\begin{array}{l}\text { 倒伏 } \\
\text { 程度 } \\
(0-5)\end{array}$} & \multirow{3}{*}{$\begin{array}{l}\text { 主茎長 } \\
(\mathrm{cm})\end{array}$} & \multirow{3}{*}{$\begin{array}{l}\text { 茎太 } \\
(\mathrm{mm})\end{array}$} & \multicolumn{2}{|c|}{ 分枝数 } & \multirow{3}{*}{$\begin{array}{c}\text { 最下着萊 } \\
\text { 節位高 } \\
(\mathrm{cm})\end{array}$} & \multirow{3}{*}{$\begin{array}{c}\mathrm{m}^{2} \text { 当り } \\
\text { 有効萊数 } \\
\text { (莢) }\end{array}$} & \multirow{3}{*}{$\begin{array}{c}\text { 百粒重 } \\
(\mathrm{g})\end{array}$} & \multirow{3}{*}{$\begin{array}{l}\text { 収量 } \\
\left(\mathrm{g} \mathrm{m}^{-2}\right)\end{array}$} \\
\hline & & & & & 株当り & $\mathrm{m}^{2}$ 当り & & & & \\
\hline & & & & & (本) & (本) & & & & \\
\hline \multirow{5}{*}{2012} & 狭畦 8.9 株 $\mathrm{m}^{-2}$ & 2.3 & $59 \mathrm{~b}$ & $8.9^{\mathrm{ab}}$ & $5.5^{\mathrm{a}}$ & 48.7 & $16.1^{\mathrm{ab}}$ & $532^{\mathrm{ab}}$ & 29.3 & $270 \mathrm{bc}$ \\
\hline & 狭畦 13.3 株 $\mathrm{m}^{-2}$ & 2.7 & $68^{a b}$ & $8.3^{\mathrm{abc}}$ & $5.2^{\mathrm{a}}$ & 69.2 & $15.7^{\mathrm{ab}}$ & $667 \mathrm{ab}$ & 30.1 & 339 ab \\
\hline & 狭畦 17.8 株 $\mathrm{m}^{-2}$ & 2.7 & $71^{\mathrm{ab}}$ & $7.8^{b c}$ & $3.9^{\mathrm{ab}}$ & 70.0 & $17.7^{\mathrm{a}}$ & $707^{\mathrm{a}}$ & 30.1 & $384^{\mathrm{a}}$ \\
\hline & 狭畦 26.7 株 $\mathrm{m}^{-2}$ & 1.3 & $79^{\mathrm{a}}$ & $7.0^{\mathrm{c}}$ & $2.4^{\mathrm{b}}$ & 64.1 & $21.4^{\mathrm{a}}$ & $696^{\mathrm{a}}$ & 28.0 & $350^{a b}$ \\
\hline & 慣行 8.9 株 $\mathrm{m}^{-2}$ & 0.0 & $42^{c}$ & $9.6^{\mathrm{a}}$ & $5.0^{\mathrm{a}}$ & 44.5 & $8.0^{\mathrm{b}}$ & $489 \mathrm{~b}$ & 28.4 & $235^{c}$ \\
\hline \multirow{5}{*}{2013} & 狭畦 8.9 株 $\mathrm{m}^{-2}$ & 0.0 & $49 \mathrm{~b}$ & $7.3^{\mathrm{ab}}$ & $4.4^{\mathrm{a}}$ & 39.2 & $16.3^{b}$ & $604^{\mathrm{ab}}$ & 29.8 & $309 \mathrm{ab}$ \\
\hline & 狭畦 13.3 株 $\mathrm{m}^{-2}$ & 0.3 & $62^{a b}$ & $6.8^{a b c}$ & $3.1^{\mathrm{ab}}$ & 41.7 & $23.1^{\mathrm{ab}}$ & $739^{\mathrm{a}}$ & 29.4 & $330^{a b}$ \\
\hline & 狭畦 17.8 株 $\mathrm{m}^{-2}$ & 0.3 & $66^{\mathrm{a}}$ & $6.3^{\mathrm{bc}}$ & $1.9 \mathrm{bc}$ & 33.2 & $24.4^{\mathrm{ab}}$ & $671^{a b}$ & 30.0 & $354^{\mathrm{a}}$ \\
\hline & 狭畦 26.7 株 $\mathrm{m}^{-2}$ & 0.3 & $72^{\mathrm{a}}$ & $5.5^{\mathrm{c}}$ & $0.7^{\mathrm{c}}$ & 19.6 & $27.1^{\mathrm{a}}$ & $724^{\mathrm{a}}$ & 29.5 & $370^{\mathrm{a}}$ \\
\hline & 慣行 8.9 株 $\mathrm{m}^{-2}$ & 0.0 & $58^{a b}$ & $8.2^{\mathrm{a}}$ & $3.9^{\mathrm{a}}$ & 35.0 & $19.5^{\mathrm{ab}}$ & $543^{b}$ & 27.2 & $248^{b}$ \\
\hline \multirow{5}{*}{2014} & 狭畦 8.9 株 $\mathrm{m}^{-2}$ & 0.7 & $60 \mathrm{bc}$ & $9.4^{\mathrm{a}}$ & $5.1^{\mathrm{a}}$ & 45.1 & $19.5^{\mathrm{ab}}$ & 614 & 30.6 & $326^{\mathrm{b}}$ \\
\hline & 狭畦 13.3 株 $\mathrm{m}^{-2}$ & 2.2 & $72^{a b}$ & $8.4^{\mathrm{ab}}$ & $3.9^{\mathrm{a}}$ & 52.3 & $26.4^{\mathrm{a}}$ & 643 & 31.1 & $337^{\mathrm{ab}}$ \\
\hline & 狭畦 17.8 株 $\mathrm{m}^{-2}$ & 2.0 & $73^{a b}$ & $8.3^{\mathrm{ab}}$ & $3.3^{\mathrm{ab}}$ & 59.3 & $24.8^{\mathrm{a}}$ & 620 & 31.6 & $335^{\mathrm{ab}}$ \\
\hline & 狭畦 26.7 株 $\mathrm{m}^{-2}$ & 1.3 & $81^{\mathrm{a}}$ & $7.3^{b}$ & $1.9^{b}$ & 49.8 & $26.3^{\mathrm{a}}$ & 691 & 33.5 & $427^{\mathrm{a}}$ \\
\hline & 慣行 8.9 株 $\mathrm{m}^{-2}$ & 2.0 & $53^{c}$ & $8.7^{\mathrm{ab}}$ & $4.6^{\mathrm{a}}$ & 40.9 & $15.8^{b}$ & 615 & 30.4 & $338^{a b}$ \\
\hline \multirow{11}{*}{ 平均 } & 2012 & $1.8^{\mathrm{a}}$ & $64^{\mathrm{ab}}$ & $8.3^{\mathrm{a}}$ & $4.4^{\mathrm{a}}$ & $59.3^{\mathrm{a}}$ & $15.8^{\mathrm{b}}$ & 618 & $29.2^{b}$ & 316 \\
\hline & 2013 & $0.2^{b}$ & $61^{\mathrm{b}}$ & $6.8^{\mathrm{b}}$ & $2.8^{\mathrm{b}}$ & $33.7^{b}$ & $22.1^{\mathrm{a}}$ & 656 & $29.2^{b}$ & 322 \\
\hline & 2014 & $1.6^{\mathrm{a}}$ & $68^{\mathrm{a}}$ & $8.4^{\mathrm{a}}$ & $3.8^{\mathrm{a}}$ & $49.5^{\mathrm{a}}$ & $22.5^{\mathrm{a}}$ & 637 & $31.4^{\mathrm{a}}$ & 353 \\
\hline & 狭畦 8.9 株 $\mathrm{m}^{-2}$ & 1.0 & $56^{\mathrm{c}}$ & $8.5^{\mathrm{ab}}$ & $5.0^{\mathrm{a}}$ & 44.3 & $17.3^{b c}$ & $584 \mathrm{bc}$ & 29.9 & $302^{b c}$ \\
\hline & 狭畦 13.3 株 $\mathrm{m}^{-2}$ & 1.7 & $67^{\mathrm{b}}$ & $7.9 \mathrm{bc}$ & $4.1^{\mathrm{a}}$ & 54.4 & $21.7^{\mathrm{ab}}$ & $683^{a b}$ & 30.2 & $335^{\mathrm{ab}}$ \\
\hline & 狭畦 17.8 株 $\mathrm{m}^{-2}$ & 1.7 & $70^{\mathrm{ab}}$ & $7.5^{\mathrm{cd}}$ & $3.0^{\mathrm{b}}$ & 54.2 & $22.3^{\mathrm{ab}}$ & $666^{\mathrm{ab}}$ & 30.6 & $358^{\mathrm{ab}}$ \\
\hline & 狭畦 26.7 株 $\mathrm{m}^{-2}$ & 1.0 & $77^{\mathrm{a}}$ & $6.6^{\mathrm{d}}$ & $1.7^{\mathrm{c}}$ & 44.5 & $24.9^{\mathrm{a}}$ & $704^{\mathrm{a}}$ & 30.3 & $383^{\mathrm{a}}$ \\
\hline & 慣行 8.9 株 $\mathrm{m}^{-2}$ & 0.7 & $51^{\mathrm{c}}$ & $8.9^{\mathrm{a}}$ & $4.5^{\mathrm{a}}$ & 40.1 & $14.4^{\mathrm{c}}$ & $549^{\mathrm{c}}$ & 28.6 & $274^{\mathrm{c}}$ \\
\hline & 年次 $(\mathrm{A})$ & $* *$ & $*$ & $* *$ & $* *$ & $* *$ & $* *$ & $\mathrm{~ns}$ & $* *$ & $\mathrm{~ns}$ \\
\hline & 試験区 (B) & ns & $* *$ & $* *$ & $* *$ & ns & $* *$ & $* *$ & ns & $* *$ \\
\hline & $\mathrm{A} \times \mathrm{B}$ & - & $*$ & ns & ns & ns & ns & ns & ns & ns \\
\hline
\end{tabular}

倒伏程度は 0 ：無，1：微，2：少，3：中，4：多，5：甚，を表す。**＊はそれぞれ $1 \% ， 5 \%$ 水準で有意差あり，nsは有意差なしを示す（倒 伏程度：Kruskal-Wallis 検定，他項目：分散分析法）。異なる英文字間は年次別，および平均では要因別に5\%水準で有意差ありを示す（倒伏 程度：Steel-Dwass 法, 他項目：Tukey 法)

年平均で栽植密度が高くなるほど細くなった，株当たり分 枝数では両品種ともに, 各年次および 3 个年平均で栽植密 度が高くなるほど少なくなった。これらの生育特徵から， 畧立て狭畦栽培でも密植条件によって徒長気味の生育とな る（星川 1996，澤本・島田 2015）傾向が示された，畧立 て狭畦栽培での密植による倒伏程度の影響は, 両品種とも 有意な差は見られなかった。しかし「エンレイ」では 3 ケ 年平均で慣行区と, 狭畦 17.8 株 $\mathrm{m}^{-2}$ 区および 26.7 株 $\mathrm{m}^{-2}$ 区で有意差が確認され，狭畦栽培の方が倒伏程度は大き かった．年次別の傾向では，2012 年に有意差は得られてい ないが狭畦区と慣行区で倒伏程度の差が大きかった，狭畦 区は無培土条件のため土壤による支持力が慣行栽培より得 られにくいこと, 密植により徒長気味の生育となったこと に加え， 2012 年の播種 80 日後に当たる 8 月下旬頃の生育 調査では倒伏はいずれの区においても確認できなかったた め, 第 3 表より 2012 年の 9 月 6 日に 1 時間雨量 $40 \mathrm{~mm}$ 以
上の激しい雨が発生したことで，狭畦区の倒伏を誘発した と推察された。 2013 年は強い雨または強い風が発生した日 数は 2012 年より多かったものの, 7 月の葟照多雨が要因と 考えられる生育停滞で, 主茎長, 茎太拉よび株当り分枝数 が他の 2 ケ年より小さくなり，1株当たりの地上部重量が 減少したことで倒伏程度が緩和されたと推察された。また 2014 年はダイズ株の生育が 2012 年並に確保されたものの, 風雨は他の 2 ケ年より弱い傾向であったため倒伏が緩和さ れたと考えられた。 以上から，「エンレイ」の略立て狭畦 栽培では株の生育が良好な条件において，豪雨または強風 による影響で倒伏が起こりやすくなり, 狭畦 17.8 株 $\mathrm{m}^{-2}$ 区以上の栽植密度で慣行区と倒伏程度に差が現れる可能性 が示唆された。

最下着萊節位高は慣行区と狭畦 8.9 株 $\mathrm{m}^{-2}$ 区を比較する と，「エンレイ」では狭畦区が有意に高く，「あやこがね」 では有意差はないものの狭畦区の数值が高くなった。これ 
は培土作業の有無により地際の高低が異なったことによる 影響が大きい，最下着莢節位高が高ければコンバイン収穫 の刚り残しが解消されるため, 倒伏程度が小さい場合は狭 畦栽培によって機械収穫適性が向上することが示唆され た. 3 ケ年平均において狭畦栽培の栽植密度が高くなるほ ど，両品種とも最下着莢節位高は高くなる傾向を示した. 密植により最下着莢節位高が高まる傾向となる報告はいく つか見られ（松永ら 2003，池尻ら 2007，辻ら 2007），密植 による節間の伸長（土屋ら 1986）および，下位節の遮光に 伴う結萊率の低下（中野ら 2004）が，最下着萊節位高が高 まった要因であると考えられた。

3 ケ年平均において「エンレイ」では栽植密度が高くな るほど, $\mathrm{m}^{2}$ 当たり有効莢数が増加傾向を示し, 百粒重は 有意な差が見られなかった。 結果, 収量は増加傾向となり, 狭畦 17.8 株 $\mathrm{m}^{-2}$ 区以上から，慣行区よりも多くなった. 百粒重は前報（藤田ら 2014）とは異なり狭畦区と慣行区で 有意差が見られなかったが，本研究では狭畦区と慣行区で 雑草の発生がほとんど見られず，養水分の競合に両区で違 いが見られなかったためと考えられた。しかし2013 年で は狭畦区と慣行区で有意差が見られ，狭畦区で百粒重が大 きくなった。この年次は生育期間を通して月別降水量が多 く, 試験圃場においてダイズの立枯性病害, 特に黒根腐病 が多発生していた。黒田ら（2015）はダイズ栽培において 無培土条件が黒根腐病の発病度を軽減する傾向があること を報告しており，本試験でも黒根腐病による百粒重の低下 が，無培土条件である狭畦区では緩和されたものと考えら れた。

一方，「あやこがね」では 3 ケ年平均で，栽植密度が高 くなるほど $\mathrm{m}^{2}$ 当たり有効萊数は狭畦 17.8 株 $\mathrm{m}^{-2}$ 区が狭畦 13.3 株 $\mathrm{m}^{-2}$ 区より数值的に劣るものの増加傾向を示し, 百粒重は有意な差が見られなかった。結果，収量は「エン レイ」同様に増加傾向を示し，「あやこがね」では狭畦 13.3 株 $\mathrm{m}^{-2}$ 区以上から，慣行区よりも多くなった。2013 年の百粒重については，有意差はなかったが「エンレイ」 とほぼ同様に狭畦区で低下が緩和される傾向を示した。

\section{3. 耕うん同時畧立て狭畦栽培の適正な栽植密度}

第 4 表において, 3 ケ年平均では播種 50 日後の相対 PAR 量は 8.9 株 $\mathrm{m}^{-2}$ 以上の畧立て狭畦栽培で，新潟県の「エン レイ」における目標苗立数約 9 株 $\mathrm{m}^{-2}$ 程度に設定した慣行 栽培よりも相対 PAR 量は低く，值も $10 \%$ 以下となり十分 な雑草抑制効果が得られた。杂隹草抑制効果の観点から, 8.9 株 $\mathrm{m}^{-2}$ 以上の栽植密度設定が有効な条件であると考えられ た。ただし生育停滞する年次は， 8.9 株 $\mathrm{m}^{-2}$ 程度の畧立て 狭畦栽培では相対 PAR 量が $10 \%$ を上回り十分な被覆力を 得られない場合もあるので，雑草管理には適正な除草剤散 布等の組み合わせが必要であると考えられた。倒伏程度に おいては畧立て狭畦栽培では栽植密度の違いによって倒伏 程度に大きな差は見られなかった。しかし目標苗立数に設
定した慣行栽培と比較すると, 17.8 株 $\mathrm{m}^{-2}$ 以上の密植条 件での畧立て狭畦栽培では有意に倒伏程度が大きくなっ た。本試験においては 17.8 株 $\mathrm{m}^{-2}$ 以上の密植条件での倒 伏程度は 2.1 の小程度ではあるが, 密植適応性が低いと される「エンレイ」においては倒伏の危険性を少しでも回 避する必要があると考えられる。この倒伏程度の観点から, 畧立て狭畦栽培の適正栽植密度は $8.9 \sim 13.3$ 株 $\mathrm{m}^{-2}$ であ ると推察された。収量は站立て狭畦栽培で栽植密度が高く なるほど増加する傾向が見られたが，8.9〜13.3 株 $\mathrm{m}^{-2}$ で も慣行栽培程度の収量が確認され, 収量性に問題はないと 示唆された。

以上の検討結果から，新潟県の重粘土地帯で「エンレイ」 程度の密植適応性を備える品種で耕うん同時畧立て狭畦栽 培を行う場合は，適正栽植密度は倒伏程度の観点から 8.9 $\sim 13.3$ 株 $\mathrm{m}^{-2}$ 程度に抑えることで, 中耕・培土作業の省 略を図りつつ，雑草抑制効果を確保することが可能である と推察された。

次に「あやこがね」の耕うん同時㽞立て狭畦栽培におけ る栽植密度の影響を検証する。播種 50 日後の相対 PAR 量 は「エンレイ」と同様の傾向を示し, 8.9 株 $\mathrm{m}^{-2}$ 以上の畧 立て狭畦栽培で慣行栽培よりも相対 PAR 量は低く, 值も $10 \%$ 以下となり十分な雑草抑制効果が得られた。倒伏程度 では畧立て狭畦栽培の栽植密度の違いによって倒伏程度に 大きな差は見られなかった。 さらに慣行栽培と, 嘼立て狭 畦栽培の各栽植密度との比較でも, 倒伏程度に差が見られ なかった，密植適応性が「エンレイ」より高い「あやこが ね」では, 畧立て狭畦栽培の栽植密度は 26.7 株 $\mathrm{m}^{-2}$ まで であれば倒伏程度に影響しにくいものと考えられた。収量 は「エンレイ」同様，畧立て狭畦栽培で栽植密度が高くな るほど増加する傾向が見られた。特に 13.3 株 $\mathrm{m}^{-2}$ 以上で は慣行栽培以上の収量が確認され, 密植による増収効果も 期待できるものと示唆された。

以上の検討結果から，新潟県の重粘土地帯で「あやこが ね」程度の密植適応性を備える品種で耕うん同時㽞立て狭 畦栽培を行う場合は，適正栽植密度は $13.3 \sim 26.7$ 株 $\mathrm{m}^{-2}$ とし, 中耕・培土の省略に加えてダイズの増収効果を狙う ことが可能であると推察された。

謝辞：本論文の作成に当たり，担当教官である高橋教授 とともにご指導して下さった, 新潟大学農学部の大山卓爾 教授に深く感謝の意を表します。

\section{引用文献}

藤田与一・服部誠・樋口泰浩・南雲芳文・細川寿 2014. 耐倒伏性夕゙ イズ品種「タチナガ八」の耕うん同時㽞立て狭畦栽培による生育, 収量および抑草効果への影響. 日作紀 83: 216-222.

古畑昌巳 ·足立一日出 - 大野智史 2011. 固場排水性の良否が北陸地 域のダイズの乾物と子実生産に及ぼす影響. 日作紀 80: 65-72. 星川清親 1996. 新編食用作物 第13版. 株式会社養賢堂, 東京. 416-459. 池田武 2000. ダイズ個体群の純生産に関わる要因. 日作紀 69: 12-19. 
池尻明彦 - 岡本賢一 - 中司祐典 - 吉永巧 - 中山暁子 - 小林行高 - 金 子和彦・岩本哲弥・村山秀樹 2007. 大豆品種「サチユタカ」の機 械化体系に対応した栽培技術 第1 報 播種期および栽植密度. 山口 農試研報 56: 51-61.

片山勝之 . 大野智史 - 細野達夫 - 細川寿 - 野村幹雄 2012. 狭畒密植 栽培によるオオムギ跡ダイズの播種期と栽植様式が収穫期の全乾 物重と莢乾物重および杂隹草抑制に及ぼす影響. 北陸作報 47: 65-68.

気象庁 2015a. 過去の気象データ. http://www.data.jma.go.jp/obd/stats/etrn/ index. php (2015/12/10 閲覧).

気象庁 2015b. 雨の強さと降り方. http://www.jma.go.jp/jma/kishou/know/ yougo_hp/amehyo.html (2015/12/10 閲覧).

気象庁 $2015 \mathrm{c}$. 風の強さと吹き方. http://www.jma.go.jp/jma/kishou/know/ yougo_hp/kazehyo.html (2015/12/10 閲覧).

黑田智久 · 松澤清二郎 - 藤田与一 - 川上修 2015. 狭畦無培土栽培に よるダイズ黒根腐病発病軽減効果. 北陸病虫研報 $64: 35$.

松永亮一・高橋将一・小松邦彦 2003. 耐倒伏性に優れるダイズ新品 種「サチユタカ」の密植 - 無中耕無培土栽培. 日作九支報 69: 5355.

御子柴公人 · 松沢宏 - 荻原英雄 - 広間勝己 - 丸山宣重 堀内寿郎 1974. 大豆新品種「エンレイ」の育成とその特性について. 長野農 試報 38: 37-39.

長岡市危機管理防災本部 2014. 平成 25 年 7 月 $\cdot 8$ 月豪雨（被害の概 要) 平成 26 年 9 月 1 日現在. http://www.bousai.city.nagaoka.niigata. jp/wp-bousai/wp-content/ uploads/2013/08/681adfea1be75c9c3e126e4 678c77193.pdf (2015/12/10 閲覧).
中野尚夫・河本恭一・石田喜久男 2001. ダイズにおける栽植様式が 節位別分枝の発生と生育に及ぼす影響. 日作紀 70: 40-46.

中野尚夫 ·平田清則 · 大西政夫 2004. ダイズの栽植密度による光受 容の変化と生育・収量. 日作紀 73: 175-180.

中世古公男 ·後藤寛治 1975 . 豆類の生産生態に関する比較作物学的 研究 第 3 報大豆の密度反応性について. 日作紀 44 (別 2): 71-72.

野口勝可 · 中山兼徳 ·高林実 1977. 畑作物と杂隹草の競合に関する研 究第1報作付の差異が杂隹草群落に及ぼす影響. 日作紀 46: 504-509.

野口勝可 · 中山兼德 1978. 畑作物と雑草の競合に関する研究 第 3 報 遮光処理が杂隹草の生育に及ぼす影響. 日作紀 47: 56-62.

大泉久一 1962. 大豆の分枝発生機構並びにその栽培学的意義に関す る研究. 東北農試研報 25: 1-95.

齊藤邦行・磯部祥子. 黒田俊郎 1998. ダイズ収量成立過程における 花器の分化と発育について - 萊数と花蕾数の関係-. 日作紀 67 : 70-78.

齊藤邦行・西村公仁子 · 北原利修 2012. ダイズの倒伏が子実収量に 及ぼす影響 - 倒伏防止処理と人為的倒伏処理 - . 日作紀 81: 27-32.

澤本和徳・島田雅博 2015. 密植栽培がダイズ「里のほほえみ」の生 育および収量に及ぼす影響. 北陸作報 47: 65-68.

土屋武彦・紙谷元一・佐々木紘一 1986. ダイズの最下着萊位置の年 次および栽植密度による変動. 北海道立農試集報 55: 13-21.

辻博之. 大下泰生・君和田健二 2007. 北海道ダイズ品種の生産に及 ぼす密植・狭畦栽培の影響. 日作紀 76 (別 2): 64-65.

矢ヶ崎和弘・高松光生 · 山田直弘 - 田中進久 ·高橋信夫 2000 . ダイ ズ新品種「あやこがね」の育成. 北陸作報 35: 50-52.

Appropriate Planting Density of Two Soybean Cultivars Differing in Adaptability to Dense Planting in Ridge-making Narrow-row Cultivation : Yoichi Fujita ${ }^{1)}$, Osamu Kawakami ${ }^{1)}$, Tomohisa Kuroda ${ }^{1)}$, Makoto Hattori ${ }^{2)}$, Yasuhiro Higuchi ${ }^{1)}$, Yoshifumi Nagumo ${ }^{1)}$ and Yoshihiko Takaнаsнi ${ }^{3)}\left({ }^{1)}\right.$ Niigata Crop Res. Center, Nagaoka 940-0826, Japan; ${ }^{2}$ Niigata Prefectural Department of Agriculture, Forestry and Fisheries; ${ }^{3)}$ Graduate School of Science and Technology, Niigata University)

Abstract : We evaluated the appropriate planting density in ridge-making narrow-row cultivation of two soybean cultivars "Enrei" and "Ayakogane" in drained paddy fields with heavy clay soil in Niigata prefecture. Two cultivars differed in their adaptability to dense planting cultivation. The relative photosynthetically active radiation (PAR) under the plant canopy with narrow row cultivation decreased with increase in the planting density. The relative PAR at any planting density was less than $10 \%$ at the flowering stage, which was sufficient to suppress weed growth. Higher planting density led to more spindly growth at the maturing stage in both cultivars. The lodging index of "Enrei" in narrow row cultivation with the planting density over 17.8 plants $\mathrm{m}^{-2}$ was higher than that in conventional cultivation with $75 \mathrm{~cm}$ interrow space and 8.9 plants $\mathrm{m}^{-2}$. The lodging index of "Ayakogane" in narrow-row did not differ from that in conventional cultivations. The seed yield of both cultivars tended to increase with increasing planting density. The seed yield of "Enrei" cultivated at a planting density over 17.8 plants $\mathrm{m}^{-2}$ was significantly higher than that under conventional cultivation. The yield of "Ayakogane" was also increased at a planting density over 13.3 plants $\mathrm{m}^{-2}$. The appropriate planting density to avoid lodging in ridge-making narrow-row cultivation of "Enrei" was judged to be 8.9-13.3 plants $\mathrm{m}^{-2}$ to avoid lodging, and that of "Ayakogane" 13.3-26.7 plants $\mathrm{m}^{-2}$ to promote seed yield.

Key words : Dense planting cultivation adaptability, Lodging, Planting density, Relative PAR, Ridge-making narrow-row culture, Soybean, Yield. 